\title{
ROSTOS NO ESPELHO: PASSAGENS JUVENIS NA LITERATURA DE JOÃO GILBERTO NOLL
}

\author{
Cristina Maria da Silva ${ }^{1}$ \\ Bruno Duarte Nascimento ${ }^{2}$
}

\begin{abstract}
"Olhava-se no espelho como a pedir ao rosto que the mirava um socorro em surdina, até um empurrão quem sabe, pois ele, sem ajuda, era lento em demasia para extrair de si um futuro razoável, com barba, músculos, um beijo em certa mulher que ele conhecia desde sempre."
\end{abstract}

(NOLL, 2009, p. 18)

"Antes de sair de sua esfera encantada costumava se mirar ao espelho para verificar se tudo estava bem". (NOLL, 2010, p.13.)

\begin{abstract}
Resumo: A presente proposta busca refletir sobre a literatura juvenil de João Gilberto Noll, através dos livros Sou Eu! (2009), O Nervo da Noite (2009) e Anjo das Ondas (2010). Tomamos como referências para essa leitura as reflexões teóricas de Walter Benjamin, Norbert Elias, Michel Maffesoli, Elisabeth Badinter, Maria Rita Kehl e, claro, entrevistas e reflexões do próprio escritor sobre sua obra. Diante de seus reflexos no espelho, os adolescentes que protagonizam esses escritos se deparam com o mundo e com as incertezas sobre o que são e o que querem ser. Fazemse presentes nas narrativas: a suspensão do tempo, o trânsito entre cidades e entre as travessias da infância para a adolescência, bem como a passagem para um processo civilizador que controla as pulsões, regula os afetos a partir da experiência dos protagonistas entre o fim da infância e 0 limiar de um novo mundo.
\end{abstract}

Palavras-chave: Literatura Brasileira Contemporânea; Literatura Infantojuvenil; Rastros Humanos

Na primeira página, do livro Sou Eu!, de João Gilberto Noll (1946-2017), encontramos a imagem de sapatos, como se deles saísse uma lama escura. Por onde eles teriam caminhado? Que pés os teriam calçado? Em frente deles marcas como se fossem digitais, os pés deixam rastros, eles falam dos passos. De algum modo, sabemos que um humano os usou aqueles sapatos, e agora descalço para onde foi? Na página seguinte, vemos sandálias, que indicam descanso. Férias? Os dois calçados pertenceriam a duas pessoas diferentes ou são da mesma pessoa? São os primeiros indícios do texto.

1'Doutora em Ciências Sociais pela Universidade Estadual de Campinas-UNICAMP. Pós-doc em Antropologia UNICAMP, 2010. Pós-doc em Letras PUC-MG, 2019. Professora Associada do Departamento de Ciências Sociais-UFCE. Coordenadora do Grupo de Estudos e Pesquisas Rastros Urbanos. E-mail: crimasbr@gmail.com

${ }^{2}$ Bacharel e licenciado em Ciências Sociais (UFCE). Mestrando em Sociologia (PPGS/UFCE). Email: brunoduartenascimento@gmail.com 
Texto esse escrito num formato de diário, um pequeno caderno, no qual a narrativa é disposta em linhas pautadas. Aos poucos, sabemos que sim, "menino urbano em férias" em Ribeirão Alto, um lugar perdido, menciona o narrador. Os sapatos ou as sandálias seriam seus. Teria trocado os sapatos pelas sandálias e agora descalço está de férias? São indícios que imaginamos através do que o narrador nos conta.

Em Sou Eu!, o narrador conta-nos a experiência de uma criança tornandose adulta. O protagonista do romance é um indivíduo do gênero masculino, residente na metrópole. O menino deixa a casa dos pais nas férias escolares e, sozinho, vai passar o tempo de pausa dos estudos em um espaço fora da cidade, no interior. A maior parte da história ocorre nesse lugar, que é também "a terra de seu pai", espaço no qual as suas raízes familiares estão fincadas.

Esse menino urbano poderia ser inicialmente descrito como qualquer menino vindo do meio urbano para passar férias numa área rural. Mas na página 17 ele é chamado de "o menino das cidades" (NOLL, 2009, p.17), quase uma adjetivação do seu pertencimento ao meio urbano, mas não apenas a uma cidade, mas a várias cidades, no plural, sinalizando diferentes origens e pertencimentos. É também chamado de "colega das cidades", (p.20), "o garoto das cidades" (p. 31), "o garoto urbano", "garoto das motos e avenidas" (p.36), e ainda "o garoto dos viadutos e baladas." (p. 24).

Ele está com "seu colega campesino", (p.13), também descrito, como "seu amigo dos campos em flor", (p.18), "menino caipira", "pequeno sertanejo" (p.20), "pequeno caipira", "camarada campesino, (p.21), "guri dos campos",(p.22), "o menino rural" (p.28), "o menino dos campos floridos", (p.30), " o rapaz da poeira da estrada", "o garoto do rio e das cigarras" (p.37). Todas essas descrições parecem nos remeter a inúmeras possibilidades que se acenam na adolescência, mas que nem sempre se confirmam na vida adulta.

Sugerindo, talvez, um vínculo primaveril, algo que nasce como as flores, devagar, suave e tendo apenas o intuito de desabrochar. Ou mesmo esse pertencimento às águas do rio e às cigarras, como esse outro espaço, que é apresentado ao garoto das cidades, um outro modo de ser, sem pressa, ao correr das águas e ao canto ruidoso de prazer da cigarra. 
Por meio dessas designações, o narrador monta um jogo de alteridades marcado, principalmente, pela distinção das origens geográfica e culturais entre o protagonista da trama e o outro personagem com o qual ele estabelece relação ao longo da história. Através desse conflito, ora acentuado, ora apaziguado, o personagem principal atravessa a experiência de transição para a vida adulta.

O processo de saída da posição de criança para a de adulto é narrado por meio da experiência do protagonista "entre o fim da infância e o limiar de um mundo novo", "em um único dia de verão" (NOLL, 2009, p. 37) no campo.

O limiar (schwelle= intumescer; inchar; dilatar), nas palavras de Benjamin (2009), é a zona que sinaliza a mudança, a transição e o fluxo. Esse se diferencia da fronteira (Grenze), pois esta define o limite em que os contornos de um território ou os limites de um domínio ou a passagem de um a outro são reconhecíveis e visíveis.

Os dois são apresentados como de origens diversas: um enraizado no mato, o outro na cidade grande. Ambos agora ali, diante um do outro para um mergulho no rio. Sabemos também que é verão quando esta cena acontece. Os dois jovens arremessam-se inteiros na água, cigarras cantavam enquanto os dois pisavam no lodo escorregadio: "Dois garotos em estado de graça solar" (NOLL, 2009, p. 24). Jovens, alegres, inebriados pelo calor, mas também pelo início da adolescência e as oscilações de sentimentos e sensações.

Nas histórias e provérbios populares, durante a mesma estação dos garotos, o verão, enquanto a formiga está preocupada com o trabalho e a busca por alimentos, a cigarra está a cantar, saltitante aproveitando a beleza da paisagem, sem preocupações com o futuro. Imagem é aqui talvez acionada talvez para lembrar do lazer, da não obrigação diante da rotina e do lugar do prazer, presentes, sobretudo numa condição ideal da infância.

$\mathrm{Na}$ fábula ${ }^{3}$, para a formiga, o verão é o momento apenas para pensar em trabalho, preocupada com o amanhã e em guardar alimento para os dias invernosos. Para a cigarra, no verão é preciso viver as alegrias e prazeres que não podem ser adiados, precisam ser vividos aqui e agora. É preciso colher o dia e aproveitar a vida. No inverno, vendo a cigarra sem comida, as formigas hesitam

\footnotetext{
${ }^{3}$ Fábula atribuída ao escritor Esopo que viveu na Grécia antiga entre 620 - 564 a.C.

Revista de Letras JUÇARA, Caxias - Maranhão, v. 03, n. 01, p. 214 - 234, ago. 2019 | 216
} 
num primeiro momento, mas depois entendem que precisam acolhê-la, porque, apesar de no mundo das formigas todos trabalharem, elas percebem que a cigarra também cumpre o seu dever: ela canta para elas.

Eles já tinham chegado na beira. Tiraram as camisas. Elas ficaram lado a lado sobre a relva. Mais cigarras cantavam, enquanto os dois pisavam no lodo escorregadio do fundo. Presenças paralelas e encardidas dos dois ficaram ali, estiradas na grama rude. Tinham o odor concentrado de suor. Essas camisas saberiam esperar pelo corpo em carne e sangue de cada um. (NOLL, 2009, p. 14)

\section{Passagens: entre rios, espelhos e sonhos}

O mergulho no rio aciona a passagem entre a adolescência e a vida adulta ${ }^{4}$. Noll, ao falar de seus personagens, sempre diz se tratar do mesmo, desmemoriado, demente, que perambula em busca de sentidos e de si mesmo, tendo como lugar apenas o próprio corpo. Nas travessias dos adolescentes aqui tratados, é como se "conhecêssemos os personagens de Noll na adolescência" 5 , no início quando se projetou toda a dúvida, incerteza e mal-estar que carregam. Só para lembrar, o limiar da infância, remete à etimologia infans, que quer dizer sem fala. As definições de si ainda estão perpassadas pelos outros.

Nas palavras de Noll: "Esse homem que perpassa toda a minha ficção, embora não tenha continuidade ipsis literis, esse homem é uma coisa em cada ficção, mas é sempre o mesmo personagem ${ }^{6}(\mathrm{NOLL}, 2003$, n. p). Em outra entrevista, também afirma: "eu trato desde o início com o mesmo personagem, mesmo que não haja, de um livro para outro, uma continuidade explícita. Os

\footnotetext{
${ }^{4} \mathrm{O}$ banho de rio ou a travessia entre as margens de um rio é um recurso amplamente abordado no imaginário literário, podemos ver isso, por exemplo na literatura brasileira de Guimarães Rosa, em Grande Sertão: veredas (1956), Diadorim só tomava banho de rio sozinho e à noite. O rio também é personagem no conto $A$ terceira margem do rio (1962). Na literatura moçambicana de Mia Couto, o rio é uma metáfora muito presente na composição de seus romances, como em Um rio chamado tempo, uma casa chamada terra (2002) e nos contos de Estórias Abensonhadas (1994). Na literatura do angolano Luandino Vieira esse também é tomado como estratégia narrativa, por exemplo em De rios velhos e guerrilheiros. O livro dos rios, publicado em 2006. Mia Couto e Luandino Vieira leitores de Guimarães Rosa.

${ }^{5}<$ https://tvcultura.com.br/videos/28249_entrelinhas-joao-gilberto-noll.html. >

${ }^{6}$ NOLL, João Gilberto. Depoimentos: O Avesso do Conhecimento. In: CHIODETTO, Eder. O Lugar do Escritor. Cossac \& Naify: Correio Brasiliense, 10 de novembro de 2002.
}

Revista de Letras JUÇARA, Caxias - Maranhão, v. 03, n. 01, p. 214 - 234, ago. 2019 | 217 
contextos dramáticos podem se diferenciar, mas o homem está ali, sem nome, e ele habita em mim" 7 .

O escritor afirma que os seres que habitam seus livros são "sempre andantes, à procura quem sabe de emprego, de amizade, de sexo, de casa, pois que geralmente são personagens sem teto, à procura de uma qualificação qualquer, embora muitos já estejam acovardados" (NOLL, 2006, p. 20). E os adolescentes? Poderíamos indagar, o que eles buscam nesse limiar da adolescência?

Através do espelho e das metáforas, do banho de rio e da travessia para a outra margem, o garoto urbano de Sou Eu! olha e vê a si mesmo, no espelho, no banho de rio, na penumbra, no rosto do outro. As diferenças entre os dois se misturavam, eles pareciam compartilhar a mesma infância e ambos estavam com um pé na adolescência. Mas o narrador nos pergunta: "Parecia uma quebra entre o rapaz da poeira da estrada e o garoto urbano que sempre se imaginara o único. Tinham sido uma pessoa só?" (NOLL, 2009, p. 36).

O narrador descreve que a euforia das águas parecia não só deles, mas de toda a natureza. Nesse momento, ele indica: "Sem a menor ideia de que havia ao redor uma suspensão do tempo." (NOLL, 2009, p. 17). A expressão "não tinham a menor ideia" é algo comum na descrição e na construção dos personagens de Noll, pois suas ações são sempre arrancadas do inconsciente. Os rastros do inconsciente se fazem presentes na composição narrativa para nos lembrar como as pulsões, aquilo que não sabemos marcam as nossas ações e o que somos. Os garotos, ainda na travessia da infância para a adolescência, não tinham total consciência nem da transformação em seus corpos ao toque das águas, nem de que ali estavam num outro tempo, um tempo suspenso, do Instante Eterno, no qual um tempo roubado, um tempo vagaroso e sem obrigações se sobrepõe.

Se a modernidade se fundou num tempo da utilidade e linear, isso fez com que o tempo da história individual fosse lido como o tempo da história social e lido de maneira hegemônica com princípio, meio e fim (MAFFESOLI, 2003). Nos tempos atuais, os mesmos pressupostos parecem não se sustentar. Se pensarmos

\footnotetext{
7 Entrevista: João Gilberto Noll. Coluna G1. Máquina de escrever. 25. set. 2008. Sobre isso Cf. Rastros das Socialidades, 2014, onde essa discussão é mais detalhada abordando a obra de João Gilberto Noll.
}

Revista de Letras JUÇARA, Caxias - Maranhão, v. 03, n. 01, p. 214 - 234, ago. 2019 | 218 
no tempo dos rituais e, no caso, aqui do ritual de passagem entre a infância e adolescência, estamos lidando com um outro tempo: o da lentidão, suspenso e no qual a contemplação tem seu lugar. O mundo é vivido aqui e agora, tal como ele é: caótico, imprevisível e pleno de incertezas. Há um certo "presenteísmo" para continuarmos com a reflexão de Michel Maffesoli, que se traduz na fuga de uma temporalidade da utilidade e da linearidade. A vida não se reduz a simples funcionalidade e finalidade, sobretudo, para as novas gerações que vivem a uma espécie de eternidade cotidiana, ou seja, são indiferentes ou mesmo hostis ao mundo social e econômico e direcionam todos as suas forças para a realização de seus desejos. Citando agora o trecho completo da página 17 podemos ler:

\begin{abstract}
De súbito os garotos se jogaram inteiros na água. (...) De supetão deram para saltar. Os corpos estavam cobertos de gotas peroladas, e dos lóbulos pendiam ínfimos pingos-d'água feito brincos, onde se viam refletidas as cores quase ápice do dia. O som estabanado que a água produzia, com braços e pernas, escancarava a euforia até ali subentendida. Euforia não só dos dois, mas de toda a Natureza em volta. As folhas filtravam o sol. (...) Sim, em torno, as árvores, o horizonte, os tufos de capim, o próprio céu pareciam dilatar a sua beleza para se oferecerem especialmente àqueles dois a dar caldo um no outro, soltando risadas, sem a mínima ideia de que havia ao redor uma suspensão do tempo ao infinito (NOLL, 2009, p. 16-17).
\end{abstract}

O garoto da cidade sabe apenas que precisa se acostumar com o fato de ocupar o mesmo corpo e buscar dele não se extraviar. Bate no próprio rosto como reprimenda pela "evasão do instante." É como se, nesse início da adolescência, ele de algum modo antevisse a fúria do corpo e os extravios dos personagens de Noll, no auge da vida adulta. Ele oscila não apenas entre o calor do verão e a fria escuridão de um túnel entre as árvores, são as próprias emoções que oscilam, pedindo para que ele tateie a realidade, para entre a confusão, a vertigem e a volta para si mesmo, dominar "a noção das coisas ao redor." (NOLL, 2009, p. 33). "Escuta o que ainda não sabem escutar" (NOLL, 2009, p. 26).

Os dois experimentam no verão, uma alegria desvairada: "O menino da cidade saiu do rio, sentou na margem e tentou se concentrar mais uma vez no seu próprio eixo. Mas no momento era difícil voltar para dentro de si mesmo" (NOLL, 2009, p. 22). As sensações o levam à percepção de estar em uma festa. O encontro de corpos, o toque do outro, fazendo uma das primeiras descobertas da saída da infância, que "os corpos emanam calor." (NOLL, 2009, p. 33). Enquanto caminham Revista de Letras JUÇARA, Caxias - Maranhão, v. 03, n. 01, p. 214 - 234, ago. $2019 \mid 219$ 
o vento os tange, dentro desse mesmo dia, eles atravessam juntos "a fronteira entre a inocência e o entendimento." (NOLL, 2009, p. 26).

O menino das cidades ainda não conhece bem o novo rosto dessa passagem entre a infância e a adolescência. A narrativa oscila entre o banho de rio, descrito no passado, e os momentos em que ele está diante do espelho se questionando sobre quem é diante do espelho. O garoto diante do espelho está com uma lâmina de barbear do pai, desenhada na página 19, envolta em pelos. Ele não sabe bem como daquele rosto, ainda marcado pelos traços da infância, se extrairá um futuro.

\begin{abstract}
Um rapaz de barba recentíssima, que ainda não sabia vislumbrar a cara que teria no futuro próximo, quando enfrentasse enfim mais o dia como adulto. Por isso ele estava ali, na frente do espelho. Passava o aparelho de barbear do pai pelos dois lados da face. E se sentia ainda incapaz para o novo rosto que custaria a brotar. (...) ....estava ali, tentando raspar 0 buço, para que, como um planta que renasce mais forte pela poda, a barba pudesse se instalar definitivamente e em seu semblante revelar um homem já completo." (NOLL, 2009, p. 18)
\end{abstract}

O espelho é, geralmente, uma metáfora acionada para refletir sobre momentos de autoconhecimento. No texto sobre Os Espelhos, Jorge Luís Borges narra o horror de estar diante dos espelhos, esse vidro impenetrável, inabitável, onde se encontram impossíveis espaços de reflexos. Superfície silenciosa diante da qual ele ainda não sabe porque sente medo. Talvez por multiplicarem o mundo? Não é só um vidro, ele nos espreita:

\author{
Prolongam este inútil mundo torto \\ $\mathrm{Na}$ vertigem de seus emaranhados; \\ São às vezes de tarde embaçados \\ Pelo alento de alguém que não está morto. \\ $O$ vidro nos espreita. Se entre as quatro \\ Paredes do quarto existe um espelho, \\ Já não estou sozinho. Há outro. Há o reflexo \\ Que arma na aurora um sigiloso teatro. (BORGES, 2000, p. 41)
}

Ao ser indagado sobre como essa imagem dos protagonistas diante do espelho é recorrente em sua obra, como em Hotel Atlântico e em Lorde, Noll ressalta como esse estar diante do próprio reflexo é nesses romances a imagem do corpo que se deteriora, os personagens não têm certeza sobre esse "eu" refletido.

Revista de Letras JUÇARA, Caxias - Maranhão, v. 03, n. 01, p. 214 - 234, ago. 2019 | 220 
É o momento em que o personagem não sabe se isso que chamam de "eu" está representando de fato a ele próprio. Então ele precisa ver no espelho que existe essa forma humana que o representa. Da qual ele foge, porque quer ser todo mundo e ninguém, ao mesmo tempo. Por que meus personagens caminham tanto? Eles gostam de se dissolver na multidão, ser um pouco cada um, e com isso ninguém. Então, realmente existe essa dialética entre todo mundo e ninguém, e por isso ele vai ao espelho, para ver que não é um outro. Coisa que acontece no Lorde: ele acaba por ser um outro. No fundo, ele queria ser um outro, quem não quer? Com toda essa enxurrada de publicidade, desses indivíduos impolutos tendo sua ninhada satisfeita, sorridente, chegando em casa, a mulher o recebendo sorrindo. Como não achar que a gente está desfalcado nessa sociedade? É muito interessante realmente, em Lorde ele se transforma em um estivador, que é puro corpo, pura força corporal, pura solidez. (NOLL, 2013, n. p)

No caso do adolescente de Sou Eu!, o começo dessa dúvida surge diante da imagem e da constituição de si. Importante notar que o próprio título termina em uma exclamação. "Sou Eu!", apesar das incertezas, esse que está diante do espelho tenta se afirmar sobre quem seja ou, pelo menos, quem consegue ver naquele momento. É um modo de encarar a alteridade desse outro que agora desperta não de fora, mas de dentro de si. A lâmina desenhada, talvez ilustre como dela são tirados não apenas os pelos, mas as peles da infância, os vestígios da inocência e certa ingenuidade.

Os traços tanto dos outros quanto de suas opiniões. Crescer é andar sozinho, é construir um caminho próprio, com olhos fixos nesse rosto que desponta como uma máscara sendo arrancada de dentro de si mesmo. Essa travessia entre a infância e a adolescência não se faz em qualquer lugar, Ribeirão do Alto, ficamos sabendo na página 20, é a terra natal do pai. Na volta para casa, é a mãe quem recebe o garoto da cidade, ele olha para as próprias mãos, mas agora já não o embaralham com qualquer outra identidade. Quando ela pergunta quem é, ao se aproximar da varanda, ele responde: Sou eu. Naquele dia, de algum modo, descobriu a si mesmo, fez a travessia para o outro lado da margem do rio da vida.

Nesse trajeto de retorno, o "menino urbano" testemunha a partida do "menino do campo":

Foi quando no lago negro um barco começou a se mover e a aproximar. De início o garoto das cidades pensou estar diante de um evento cenográfico. No barco havia um homem de pé, com um candeeiro na mão. A embarcação atracou bem na frente dos dois amigos. Sem dizer palavra, o barqueiro fixou o olhar no menino dos campos em flor. Mais ele não precisava fazer. O menino, dos misteriosos bosques de Ribeirão do Alto, entendeu, entrou na canoa se equilibrando para não cair (...) olhou para Revista de Letras JUÇARA, Caxias - Maranhão, v. 03, n. 01, p. 214 - 234, ago. 2019 | 221 
o amigo das cidades e logo fez um sinal ao barqueiro que podiam partir. Ele tomava as rédeas da travessia. (NOLL, 2009, p. 34)

A imagem faz alusão à ideia de post-mortem pensada pela mitologia grega, na qual a morte não seria o fim da vida humana, mas a passagem para a eternidade. Em Hades, havia um barqueiro chamado Caronte. Ele se encarregava de transportar as almas de uma margem a outra dos rios do submundo. Por essa razão, ele cobrava um preço. Eram exigidas moedas de ouro como pagamento pelo serviço prestado. Este episódio da narrativa simboliza a passagem, sobretudo, a despedida do protagonista da infância no momento em que ele necessita deslocarse dela para a vida adulta. $\mathrm{O}$ narrador tornar isso explícito quando nos conta que o protagonista e o outro menino com o qual ele interage são, na verdade, a mesma pessoa:

Foi quando o menino urbano percebeu que lá na outra margem do lago negro alguém o olhava na penumbra de tudo, alguém que ele ia agora identificar, quem sabe... Foi, sim, com grave impacto que o garoto das motos e avenidas viu que se tratava justamente de sua própria face. Sentiu um calafrio e recuou um, dois passos. (NOLL, 2009, p. 36)

O personagem principal se utiliza deste alter ego como um caminho para efetuar a travessia da infância para a vida adulta. Nesse sentido, não nos referimos exclusivamente a uma mera convenção etária que arbitra sobre as fases do desenvolvimento humano. Detemo-nos no processo civilizador individual objetivado pelo protagonista. Ele encontra-se situado numa posição da qual a tendência civilizadora o convoca a subir os degraus de controle pulsional e exige uma racionalidade nas ações com vistas a atingir os objetivos a longo prazo que a vida adulta em nossas sociedades demanda. $O$ alter ego é um modo de negociar a interiorização do mecanismo de autorregulação sem, necessariamente, abrir mão das chances de gozo e satisfação de seus desejos. O narrador conta-nos que, apesar da cena da partida do alter ego do protagonista, ele ainda o espreita.

O rapaz urbano mirou fundo os olhos do amigo e indagou calado se ele era aquele caipira mesmo ou esse aqui, do outro lado, esse garoto em temporada de férias na terra do pai. Lembrou da figura que o olhava do lado de lá do lago negro. Fitava-o como mesmíssimo rosto dele, o contemplado. Exatamente como num espelho. Logo, porém, o menino do 
sertão reapareceu na remota margem das águas. Reaparecia e ao mesmo tempo se escondia, difícil de explicar. (NOLL, 2009, p. 42)

A imagem da infância do "rapaz urbano" encarnada na figura do "menino do sertão" persiste e isso não seria "difícil de explicar". O processo civilizador individual do protagonista está a se fazer. $O$ transcurso da internalização do mecanismo de autocontrole necessário à vida adulta nunca está completo. Em algum momento da adultícia, nosso protagonista, assim como qualquer indivíduo inscrito na dinâmica do processo civilizador, cai dos degraus dos níveis de autorregulação socialmente prescritos. De acordo com Norbert Elias (2016), o processo civilizador está sujeito às mudanças decorrentes dos modos como as relações de interdependências constituem figurações. Em consequência disso, os padrões de controle e de regulação dos indivíduos estão suscetíveis a maiores ou menores possibilidades de frouxidão e de restrição.

Em O Nervo da Noite, o narrador conta-nos alguns dos dilemas da transição do protagonista da infância para a fase adulta por meio da experiência de um sonho. Tal qual o protagonista de Sou Eu!, trata-se de um garoto do gênero masculino, residente na metrópole. Além disso, o narrador dá indícios de sua classe social de origem: "A mão era lisa, de alguém que jamais tocara na terra como ofício. Um garoto vivendo em berço esplêndido? Talvez seu exercício manual se resumisse a tocar nas teclas do computador. Às vezes, do piano" (NOLL, 2009, p. 32).

O menino de classe abastada sonha e imagina-se dentro de uma casa abandonada durante a noite. Sua única companhia é um cachorro. No entanto, no decorrer do sonho, ele percebe que a aparição do animal não passou de fruto da fantasia de sua cabeça. Naquele espaço "em ruínas" projetado pela sua imaginação, o protagonista tem como objetivo resolver alguns dos impasses que ele teme enfrentar na vida adulta.

O jovem então compreende de fato está só, e que só dessa solidão pode tirar seu arrimo para a madrugada chuvosa. Ele teria de enfrentar a noite inteira, sem ter a quem chamar. Era isso ser uma pessoa adulta? Era isso, despistar o medo para pode chegar ao dia seguinte sem olheira nem tremores?. (NOLL, 2009, p. 29) 
Na cena, o garoto depara-se com a situação de estar só, isto é, vê-se imerso em sua "vida interior", tendo que lidar com as suas emoções, como, por exemplo, o medo. Atravessar o processo civilizador individual em sociedades complexas como as nossas requer o desenvolvimento de uma economia psíquica dos afetos, como um modo de ajuste das emoções a níveis socialmente aceitáveis.

O autocontrole gestado pelo processo civilizador experimentado pelo protagonista o leva a planejar a sua vida dentro de uma perspectiva a longo prazo. "Passar às ações", como mostra-nos o narrador, aponta-nos que o garoto passaria a arquitetar um projeto de vida tendo em vista algum objetivo. No caso, o de sobreviver de forma independente. A conquista da autonomia da vida adulta tem um preço a cobrar. Faz-se necessário ao protagonista internalizar os mecanismos de autorregulação, a fim de responder às demandas de alta previsibilidade e autocontrole que a posição de adulto em nossas sociedades exige.

\begin{abstract}
Se chegasse mesmo a dormir e despertar, o que faria da manhã? Como conseguiria o pão e o leite na primeira refeição do dia? Aprenderia depressa a trabalhar para sobreviver? Mas quem o poderia empregar? Quem mais além de mim?, ele suspirou dando um ponto final em suas indagações. A chuva começava a cair e ele meditou que de agora em diante precisaria passar às ações. Que agora, sem o guarda-chuva dos pais, ele teria de ganhar o dia com o seu próprio suor. (NOLL, 2009, p. 29).
\end{abstract}

Em Anjo das Ondas, o narrador conta-nos a história de Gustavo. Tal qual os outros dois protagonistas de Sou Eu! e O Nervo da Noite, ele é um jovem do gênero masculino, residente na cidade. Semelhante ao personagem principal de $O$ Nervo da Noite, Gustavo é oriundo das classes sociais abastadas. Na narrativa, tal condição evidencia-se por meio dos deslocamentos geográficos que o garoto faz, os lugares pelos quais transita e a formação dos pais e da avó materna. Aliás, o narrador monta a figuração familiar dentro da qual Gustavo está inserido. Seu pai é um escritor que vivia num dourado isolamento e abandono, e sua mãe é uma professora de física. A avó materna é uma cantora lírica que reside em Londres, capital inglesa onde Gustavo passa uma temporada. Logo após, opta pelo retorno ao Rio de Janeiro para, assim, residir com o pai. O protagonista enfrenta o dilema da independência e para ele ninguém poderia o acompanhar "nessa passagem 
espinhosa." Em suas palavras: "Eu não deveria dispor de mais ninguém além de mim, seja para arrumar as malas, seja para fazer o meu check-in, seja para tudo o mais. E tudo sem olhar para trás." (NOLL, 2010, p.53). Ele sabe aqui que para conseguir se ocupar de si mesmo tinha que se divorciar dos laços que o ataram até aquele momento.

Gustavo diz:

Naquele momento, é claro, eu tinha de me divorciar dos pais, não deveria seguir suas trilhas, e isso ameaçava qualquer otimismo, por representar um rompimento de choque, sim, talvez com sérias consequências. Não poderia me dar ao luxo de um divórcio gradativo, manso. Isso poderia significar movimentos suaves em pleno pântano. E mesmo que eu considerasse essa drástica separação a melhor saída, a sensação de renúncia ao conforto do lar doía. Eu parecia às vezes estar tomando posse do futuro. De fato, por direito de idade, o devir já me pertencia. Entretanto, a incógnita da vida ainda por viver me castigava, enquanto eu descia as escadas do meu pai, sem saber para onde ir. (NOLL, 2010, p. 93)

Norbert Elias (2016), ao reconstruir o curso do processo civilizador dentro do qual se inscreve a relação entre pais e filhos, aponta-nos que estaríamos a viver em um período de transição no qual tem se cristalizado uma tendência menos autoritária. Contudo, ele reconhece que ela coexiste com a anterior - mais autoritária -, no seio das famílias. Gustavo, ao desejar se insurgir contra as imposições e as expectativas de seus pais, compreende que essa ação poderia desencadear um "choque" ou "sérias consequências". De fato, isso teria grandes chances de acontecer, uma vez que a sua escolha desestabilizaria o equilíbrio instável da balança de poder entre ele e seus pais. O "rompimento", na verdade, seria uma forma de efetuar uma redistribuição do poder entre a sua posição de filho e a de seus pais. Se existisse uma reação de repulsa dos pais de Gustavo à sua rebelião, ela poderia ser entendida como uma recusa deles a perder o poder de mando sobre o filho. De modo semelhante aos outros protagonistas do universo infantojuvenil de Noll, o processo civilizador de Gustavo é marcado pela exigência de uma capacidade de planejamento a longo prazo para a conquista de objetivos. Esse empreendimento só pode ter êxito se elaborado por meio de um regramento pulsional e de uma autorregulação. 
Sabia que lhe faltava ainda qualquer clara inclinação de expressar força e madureza. Sabia que ainda se sentia rudimentar para as demandas da plenitude. Afinal, por enquanto era apenas o limiar de um adulto.

(NOLL, 2010, p. 46).

A narrativa tem muitas falas de Gustavo no futuro do pretérito, ou seja, assinalando acontecimentos que poderiam ter acontecido no passado, mas que não se concretizaram ou dependiam posteriormente de uma outra situação. Para que a ação acontecesse ela estava condicionada a outra. Gustavo expressa incerteza, surpresa, indignação. Os momentos de divagação se abrem como visões de si mesmo, num lugar que ainda não ocupa, como adulto e num lugar, o da infância, onde não o cabe mais: "Correu até o espelho, viu uma face meio diluída, indeterminada, com bastante lugar para que pudesse desenhar na cara o seu futuro" (NOLL, 2010, p. 36).

Suas indagações também se dão no verão e Gustavo faz sua travessia no mesmo dia em que comemora o seu aniversário de quinze anos. Fugindo da imagem da mãe e ao mesmo tempo indo para a casa de um pai, acostumado ao desterro. Ele já não cabe em si, precisa sair, dessas casas, dessas relações.

Na parte final do romance, Gustavo encontra-se com outro garoto, também chamado Gustavo, um antigo colega de infância, e de modo semelhante ao da narrativa de Sou eu!, há aí um jogo de semelhanças e diferenças explorado pelo narrador e que põem em dúvida se falamos de duas pessoas ou de um encontro com essa dualidade em si mesmo. Gustavo diz: "Parecíamos siameses, sem entretanto, a inescapável dependência carnal. Ainda ali duas hipóteses humanas. (...) existiria sempre o outro ao lado de mim, a discutir ou a emudecer. Se existissem dois corações aí duas identidades com um único sexo." (NOLL, 2010, p. 118-119). A respeito do impasse da independência, Gustavo fala-nos: "Diante da renitente falta de autonomia frente ao pai e à mãe, esse um-em-dois deveria escolher a solidão e arder naquilo que costumavam chamar de intimidade." (NOLL, 2010, p. 119). Em outro momento, o garoto ainda diz:

De repente, na minha cabeça, minha mãe e minha avó pareciam não ter nada mais a me dar. No futuro, Londres deveria acolher a minha periclitante autonomia, até os limites de minha solidão, e em troca eu ofereceria ao Reino unido a autenticidade que até ali não soubera explorar. (NOLL, 2010, p. 58)

Revista de Letras JUÇARA, Caxias - Maranhão, v. 03, n. 01, p. 214 - 234, ago. 2019 | 226 
A ideia de autonomia encarnada por Gustavo é a de uma saída das cadeias de interdependências que ele forma com outros indivíduos. O resultado disso seria a "solidão", ou uma espécie de retorno ao seu "mundo interior" como uma forma de reclusão e, ao mesmo tempo, de afastamento daqueles que exercem algum tipo de força sobre ele. No entanto, como lembra-nos Elias (2016) não existe indivíduo que prescinda de uma rede de relações de dependências mútuas. Contraditoriamente, é por meio dela que a autonomia é conquistada. Autonomia como um modo de um indivíduo assegurar a ampliação de seu raio de ação dentro da figuração, ou das figurações que ele forma com outros.

\section{Do processo civilizador individual ao adulto civilizado}

As trajetórias dos protagonistas de Sou Eu!, O Nervo da Noite e Anjo das Ondas ensejam duas discussões. A primeira diz respeito ao transcurso pelo qual a criança em nossas sociedades desenvolve a autorregulação necessária à vida adulta. Para Norbert Elias (2016), essa passagem trata-se de um processo civilizador individual, ou seja, um processo por meio do qual o indivíduo desenvolve o controle pulsional e regulação dos afetos. A segunda relaciona-se à conquista da independência da criança a partir e por meio das relações de dependências mútuas com os pais.

Segundo o sociólogo, "em sociedades tão complexas e nada infantis como as nossas, que demandam uma alta medida de previsão e autocontrole." (ELIAS, 2016, p. 469), a exigência de uma resposta das crianças às prescrições sociais da vida adulta causa a elas e aos seus pais um grande embaraço. Tornar-se adulto impõe aos infantes o seguinte dilema: não permitir que as possibilidades de gozo e alegria se percam totalmente e, ao mesmo tempo, atingir o grau de regulação das pulsões socialmente exigido. Aos pais, as expressões instintivas das crianças os levam a instilar a vergonha e o pudor necessários nesses seres em processo de formação. Isso os faz reforçar constantemente o seu próprio nível de autorregulação. As coerções externas, as leis, as regulações são transpostas em estruturas psíquicas por meio de um mecanismo de vigilância das crianças pelos pais e da educação formal. Através disso, os pais, como adultos civilizados, são Revista de Letras JUÇARA, Caxias - Maranhão, v. 03, n. 01, p. 214 - 234, ago. 2019| 227 
impelidos a reforçar constantemente o seu processo civilizador individual, isto é, o próprio nível de autocontrole.

Elias fala-nos da necessidade da criança de viver a sua própria vida de uma maneira distinta da de seus pais. Por esse, motivo há os conflitos de interesses e desejos, recorrentes das tensões entre as relações de força entre os pais e os seus filhos. Em suas palavras:

\begin{abstract}
A relação entre pais e filhos é uma relação de dominação com uma balança de poder extremamente desigual. As crianças, no início, encontram-se completamente sob o julgo do poder dos pais. Mais especificamente, as oportunidades de poder dos pais são muito grandes se comparadas às oportunidades das crianças, principalmente no que diz respeito aos infantes. Em sociedades como as nossas, dificilmente haverá outro tipo de relação em que os diferenças de poder entre indivíduos interdependentes sejam tão grandes como na relação pais-filhos. (ELIAS, 2016, p. 475)
\end{abstract}

Não se trata de advogar a favor da liberdade total - se é que ela é possível - das crianças em relação aos pais, tampouco considerar estes algozes e aquelas vítimas. Elias abre-nos o caminho para situar as relações de poder entre as posições que ambos, pais e filhos, ocupam nas cadeias de interdependências que formam. Nesta direção, a figuração familiar passa a estar inscrita em processos sociais de longa duração e não como um arranjo de relações sociais imutável e estático. Portanto, a possibilidade de exercício do poder dos pais sobre os filhos e vice-versa, está a pender como numa balança, cujo movimento deriva da conformação da figuração familiar dentro do processo civilizador.

Os adolescentes dos livros Eu Sou Eu! e Anjo das Ondas, estão em movimento, em trânsito. Ribeirão do Alto é a terra do pai, do garoto da cidade. Gustavo em Anjo das Ondas, atravessa a infância e adolescência, entre Londres e o Rio de Janeiro. Ambos, nômades de si, encarando diante do espelho que não é apenas o reflexo no espelho que é duvidoso, toda a vida social, talvez, também o seja. Nas palavras de Michel Maffesoli:

(...) o desejo de errância é um dos pólos essenciais de qualquer estrutura social. É o desejo de rebelião contra a funcionalidade, contra a divisão do trabalho, contra uma descomunal especialização a transformar todo mundo numa simples peça de engrenagem(...) Assim, se exprimem o 
necessário ócio, a importância da vacuidade e do não-agir na deambulação humana. (MAFFESOLI, 2001, p. 32-33)

O nomadismo sofreu um cerco pelo esforço das instituições sociais para estabilizar os costumes, domesticar as paixões e moralizar os comportamentos. Porém, ele sempre ressurge, porque é um traço da condição humana. Existir, do latim existere, significa sair de. Ao mesmo tempo que ocorre o processo de socialização, a força do nomadismo instituinte da sociedade e dos próprios indivíduos, instaura as socialidades, que fazem circular as pulsões, lembrando-nos desse anseio humano pela errância. A socialidade poderia ser pensada como uma suspensão nas regras, a afirmação do presente e do cotidiano, o movimento, o corte, um sair de si, próprio da existência numa abertura a um "outro", tão presentes nas sociedades contemporâneas. Ainda nas palavras de Maffesoli:

\begin{abstract}
Qualquer que seja o nome que se lhe possa dar, a errância, o nomadismo está inscrito na própria estrutura da natureza humana; quer se trate do nomadismo individual ou do social. De alguma forma, está aí a expressão mais evidente do tempo que passa, da inexorável fugacidade de todas as coisas, de sua trágica evanescência. É tal irreversibilidade que está na base desse misto de fascinação e de repulsa que exerce tudo aquilo que se parece com mudança. Os contos, as lendas, a poesia e a ficção, têm, longamente, tratado desse tema (...). (MAFFESOLI, 2001, p. 38)
\end{abstract}

Além do processo civilizador e da domesticação dos hábitos exercendo pressão sobre a errância e o desejo de fuga, vale ressaltar que os três personagens são do gênero masculino e sobre eles paira uma cobrança para terem um segurança sobre a vida e uma determinação que nem sempre eles são capazes de responder. Elisabeth Badinter (1993) aponta como queremos crer num princípio universal e permanente de masculinidade, uma macheza que atravesse o tempo, o espaço e as fases da vida. A masculinidade é tida como um objetivo e um dever.

Ser homem é uma ordem, impressa na própria linguagem, que não expressa uma indicação, mas um imperativo: "Seja homem". Como também não vemos diferença entre a designação homem e humano, seja na língua francesa, como demonstra a autora e mesmo em português. Como se o homem fosse a referência para o representante perfeito de humanidade. Essa ordem, por si só, já indica que essa virilidade demandada socialmente (pensando aqui nas normas e regras de algumas sociedades ocidentais, como a nossa, por exemplo) não é tão

Revista de Letras JUÇARA, Caxias - Maranhão, v. 03, n. 01, p. 214 - 234, ago. 2019| 229 
evidente e nem tão natural quanto se pretende. Mais do que isso, causa intenso sofrimento psíquico, principalmente, nas fases de transição da adolescência para a vida adulta.

\begin{abstract}
A formação do macho é comandada por um dado natural, universal e necessário: seu lugar de nascimento materno. Esta particularidade do menino - ou seja, ser alimentado física e psiquicamente por uma pessoa do sexto oposto - determina seu destino de modo muito mais complexo e dramático do que o da menina. (...) Nesse esquema, o menino é sucessivamente tudo e seu contrário. Fêmeo na origem, ele é advertido a deixar sua pátria para adotar uma outra oposta, ou mesmo inimiga. Este arrancamento que lhe é imposto é também intensamente desejado. (BADINTER, 1993, p. 45)
\end{abstract}

O lugar do pai presente nas narrativas é marcado, por exemplo, através de dois momentos. Primeiro, quando o filho visita a terra do pai e, o segundo, no momento em que utiliza o seu aparelho de barbear. Fazem-se presentes as ausências ou desconfortos seja desses protagonistas com a mãe ou no alheamento do pai e o fator determinante de se ocuparem de si mesmos para serem independentes. No caso de Gustavo se afastando da mãe e da avó, lemos:

\begin{abstract}
A partir daquele ponto, tudo em mim traria uma leve sugestão de completude, apenas uma leve sugestão de que a minha autonomia daria seu ar, sim, mas o sol nascesse...

Beijei as duas antes de entrar para a sala de embarques internacionais. Eu passara um tempo em Londres como uma espécie de mascote daquelas mulheres. Mas agora voltaria ao Brasil como uma outra pessoa. Já sem as duas, passaria a me ver com o pai de mim mesmo, aquele que me conduzira sem que eu mesmo percebesse. (NOLL, 2010, p. 61)
\end{abstract}

Como se configura uma família estruturada? indaga Maria Rita Kehl. Num cenário de intensas mobilidades das configurações familiares, não podemos pensar essas relações da mesma forma e muito menos sem perceber as intrínsecas relações delas com o cenário social. A família que recebemos não é a mesma que conseguimos improvisar porque as relações já não são as mesmas.

O modelo de família burguesa oitocentista demanda renúncias que nem todos tem mais disposição para pagar. Seja na sociedade centrada no patriarca que controla a propriedade, entendendo por esta não só os bens, mas a mulher e os filhos ou mesmo das famílias fechadas em si mesmas, incestuosas, preconceituosas e maledicentes. A necessidade de civilizar se impondo acima da

Revista de Letras JUÇARA, Caxias - Maranhão, v. 03, n. 01, p. 214 - 234, ago. 2019 | 230 
vontade dos sujeitos de desejo, num processo descrito por Maria Ângela D'Incao, citada por Maria Rita Kehl, como um "processo de privatização da família." Esquecemos que foi dentro desse modelo, apesar de sua estabilidade e aparência estruturada de suas relações, que surgiram os primeiros casos de sofrimento psíquico, e dele, na Viena do século XIX, que vieram os primeiros pacientes de Sigmund Freud, que possibilitaram a investigação das neuroses e a invenção da psicanálise.

\footnotetext{
Como costuma acontecer a todos os endividados, nós idealizamos a fortuna de nossos credores. Tendemos a nos esquecer de que família era aquela, e a que custo - psíquico, sexual, emocional, - ela se manteve, durante um curto período de menos de dois séculos, como célula mãe da sociedade. (KEHL, 2016, n,p )
}

Esse modelo começa a implodir-se na metade do século $X X$, caracterizando o que a autora chama de família tentacular, com os divórcios e diferentes configurações familiares. Relações menos endogâmicas e nas quais o pátrio poder se divide entre vários adultos, como novas formatos e alianças.

$\mathrm{Na}$ narrativa de Noll, um de seus protagonistas, Gustavo, reflete: "Eu precisava aderir a algum adulto. E não deveria ser ele nem minha mãe." (NOLL, 2010, p. 85). Mesmo na casa do pai não há nenhum conforto ou sensação de completude. Estar com o pai era de algum modo também se anular, adicionar o seu tempo ao dele e sem garantias de receber nada em troca, pois o pai de costas se ocupava apenas da sua ficção. Naquele destino ele era um "dissidente." (NOLL, 2010, p. 100).

O desconforto de Gustavo, de algum modo, mostra o que Maria Rita Kehl diz ser preciso, apesar das relações tentaculares da família contemporânea, que alguém se encarregue da função paterna e dos cuidados maternais. Não é à toa que o personagem não consegue falar de si mesmo, somente com essa estrutura ao seu redor é que ele vai conseguir se configurar como um ser de linguagem.

\footnotetext{
Seja como for, cabe aos adultos que assumiram o encargo das crianças o risco e a responsabilidade de educá-las. Talvez o peso da dívida para com a família idealizada faça com que estes adultos sintam-se também em dívida com seus filhos...(KEHL, 2016, n.p).
} 
Gustavo, personagem de Anjo das Ondas, expressa sua necessidade de se afastar dos pais. Ele explica que: "Geralmente quando o pai era introvertido, a mãe compensava com sua extroversão. No meu caso calhou de serem os dois reticentes" (NOLL, 2010, p. 70). Ele precisa se afastar deles para tentar descobrir em si esse outro que nele se cala.

Às vezes eu chegava a arrotar com tantas palavras empilhadas na garganta. Bem ou mal, eu ainda podia sentir em muitas alguma força de expressão....Metade delas eu não deixava sair, por medo da decepção ao flutuarem sua indigência no espaço já tão desperdiçado. Ficavam presas na goela, sem o impulso suficiente para se tornarem fala. Eu as engolia então e logo-logo se tornavam fezes. (...) A expressão em mim doía como um parto. (...) Mas com a palavra ou sem, não podia esquecer que eu já era, sim, um homem. Um homem a prezar o seu silêncio. Quem sabe um perdedor precoce. (NOLL, 2010, p. 2010).



Fig.1: Capas dos Livros

\title{
FACES IN THE MIRROR: JUVENILE PASSAGES IN JOÃO GILBERTO NOLL'S LITERATURE
}

\begin{abstract}
The presente proposal aims to reflect about joão Gilberto Noll's infant-juvenile literature, based on the books Sou Eu! (2009), Nervo da Noite (2009) and Anjo das Ondas (2009). Our references are the theoretical reflections by Walter Benjamin, Norbert Elias, Michel Maffesoli, Elisabeth Badinter, Maria Rita Kehl and, of course, interviews with Noll and his own reflections on his work. In face of their reflections in the mirror, the teenager protagonists of these books also face the world and the uncertainties about who they are and what they want to be. The narratives are marked by the suspension of time, the flux between cities and the transitions between childhood and adolescence, as well as the civilizing process that controls pulsions, regulates affects, and, through the protagonists' experiences between childhood and the treshold of a new world.
\end{abstract}

Keywords: Contemporary Brazilian Literature; Infant-juvenile Literature; Literatura Infanto-Juvenil; Human Tracks

Revista de Letras JUÇARA, Caxias - Maranhão, v. 03, n. 01, p. 214 - 234, ago. 2019 | 232 


\section{Referências}

BADINTER, Elisabeth. $X Y$ : sobre a Identidade Masculina. Rio de Janeiro: Nova Fronteira, 1993.

BENJAMIN, Walter. As passagens. Belo Horizonte: Editora da UFMG; São Paulo: Impressa Oficial do Estado de São Paulo, 2009.

BORGES, Jorge Luis. O Fazedor. 1960. In: Obras completas de Jorge Luis Borges, volume 2 / Jorge Luis Borges. - São Paulo: Globo, 2000. Disponível em: $<$ http://lelivros.love/book/baixar-livro-o-fazedor-jorge-luis-borges-em-pdf-epub-emobi-ou-ler-online/.> Acesso em: 23. Mar. 2019.

ELIAS, Norbert. (2016). A civilização dos pais. Sociedade E Estado, 27(3), 469493.Disponível em: <http://periodicos.unb.br/index.php/sociedade/article/view/5679> Acesso em: 17 maio. 2018.

KEHL, Maria Rita. Em Defesa da Família Tentacular. 17. Fevereiro 2016. Psicologias do Brasil. Disponível em: $<$ http://www.psicologiasdobrasil.com.br/maria-rita-kehl-em-defesa-da-familiatentacular/>. Acesso em: 13. Mar.2016.

MAFFESOLI, Michel. O Instante Eterno: o retorno do trágico nas sociedades pósmodernas. São Paulo: Zouk, 2003.

Sobre o Nomadismo: vagabundagens pós-modernas. Rio de Janeiro: Record, 2001.

NOLL, João Gilberto. Sou Eu. - São Paulo: Scipione, 2009.

. O Nervo da Noite. São Paulo: Scipione, 2009.

. Anjo das Ondas. São Paulo: Scipione, 2010.

. João Gilberto Noll fala sobre seus livros e reflete sobre sua carreira na quarta entrevista da série 'Obra Completa'. Zero Hora. 03/08/2013. Disponível em: $<$ https://gauchazh.clicrbs.com.br/cultura-e-lazer/noticia/2013/08/joao-gilberto-nollfala-sobre-seus-livros-e-reflete-sobre-sua-carreira-na-quarta-entrevista-da-serieobra-completa-4222510.html>. Acesso em: 23. Mar. 2019.

. Entrelinhas João Gilberto Noll. TV Cultura. Disponível em:

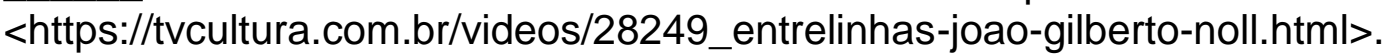
Acesso em: 08. Abr. 2019.

. Depoimentos: O Avesso do Conhecimento. In: O Lugar do Escritor de Eder Chiodetto, Cossac \& Naify. In: Correio Brasiliense. 10 de novembro de 2002. Disponível em: <http://www.joaogilbertonoll.com.br/>. Acesso em: 26. jan. 2004. 
. Entrevista: João Gilberto Noll. In: Coluna G1. Máquina de escrever. 25. Set. $2008 . \quad$ Disponível em: <http://colunas.g1.com.br/maquinadeescrever/2008/09/25/entrevista-joao-gilbertonoll/>. Acesso em: 15. out. 2008.

. Entrevista com João Gilberto Noll: Entrelivros. TV Brasil, Outubro, 2006.

SILVA, Cristina Maria. Rastros das socialidades: Conversações com João Gillberto Noll e Luiz Ruffato. São Paulo: Annablume, 2014.

A Céu Aberto: a grafia porosa de João Gillberto Noll. In: Revista Espaço Acadêmico. V. 17, N. 203. Abril/2018. Disponível em: <http://www.periodicos.uem.br/ojs/index.php/EspacoAcademico/issue/view/1500>. Acesso: Abril. 2018.

Data da Submissão: 15/04/2019

Data da Aprovação: 18/07/2019 